UDC [811.111+811.161.2]'373.7

DOI https://doi.org/10.32999/ksu2663-3426/2020-2-15

\title{
PHRASEOLOGICAL EQUIVALENTS WITH COLOR NAMES IN ENGLISH AND UKRAINIAN LANGUAGES
}

\author{
Humeniuk Iryna Illivna, \\ Candidate of Philological Sciences, \\ Head of the Foreign Languages Department \\ State Agrarian and Engineering University in Podilya \\ irynahumenyuk79@gmail.com \\ orcid.org/0000-0002-7905-9771
}

The research paper presents a study of the lexical and semantic features of English idioms with color names and their equivalents in Ukrainian based on the dictionaries. The urgency of the research is stipulated by the need to determine the theoretical and practical significance of phraseological units with color names that reflect the characteristics of national consciousness, and the study of their place in the linguistic picture of the world.

Depending on the differences in terms of expression, the degree of correspondence of interlanguage phraseological equivalents can be manifested as follows: 1) full equivalence, that is, full correlation of the expression plan and the content plan of idioms; 2) partial equivalence, which is characterized by some differences in terms of idioms expression or semantics. Full equivalents can be considered phraseological units of the English and Ukrainian languages, which have the same significative-denotative meaning, subjective-evaluative, functional-expressive connotation, structural and grammatical organization and component composition. Partial phraseological equivalents are characterized by insignificant differences in terms of expression of idioms of identical semantics, which may have a component or morphological nature. In most cases, the discrepancies relate only to the component composition of the phraseological unit, moreover, as the examples show, the components that delimit, as a rule, are lexemes of similar conceptual or related semantics. 3 subgroups are distinguished among the partial equivalents. The division depends on the compliance level of the content plan, denotative meaning, stylistic and expressive connotation, structural organization.

Summing up it is found out that despite some differences in the use of color names in the studied languages, the overwhelming majority of the idioms of the English language containing the names of colors, when translated into Ukrainian, retain their structure. Color is an integral part of a nation worldview, mentality, and is also reflected in the language of its speakers.

Key words: phraseological unit, equivalent, color names, semantic and stylistic features.

\section{ФРАЗЕОЛОГІЧНІ ЕКВІВАЛЕНТИ 3 НАЗВАМИ КОЛЬОРІВ АНГЛІЙСЬКОЮ ТА УКРАЇНСЬКОЮ МОВАМИ}

\author{
Гуменюк Ірина Іллівна, \\ кандидат філологічних наук, \\ завідувач кафедри іноземних мов \\ Подільський державний аграрно-технічний університет \\ irynahumenyuk79@gmail.com \\ orcid.org/0000-0002-7905-9771
}

\begin{abstract}
У статті представлено дослідження лексичних та семантичних особливостей фразеологізмів англійської мови з кольоропозначеннями та їхніми відповідниками в українській мові на основі словників. Актуальність дослідження зумовлена необхідністю визначення теоретичного та практичного значення фрразеологічних одиниць із назвами кольорів, що відображають особливості національної свідомості, та вивченням їхнього місця в мовній картині світу.

Залежно від відмінностей у термінах вираження ступінь відповідності міжмовних фрразеологічних еквівалентів може проявлятися так: 1) цілковита еквівалентність, тобто повна кореляція плану вираження та плану змісту фрразеологізмів; 2) часткова еквівалентність, яка характеризується деякими відмінностями з погляду плану вираження або змісту. Повними еквівалентами можна вважати фразеологічні одиниці англійської та української мов, які мають однакове сигніфрікативно-денотативне значення, суб'єктивно-оцінну, фрункціонально-експресивну конотацію, структурно-граматичну організацію та компонентний склад. Часткові фрразеологічні еквіваленти характеризуються незначними розбіжностями з погляду вираження ідіом однакової семантики, які можуть мати компонентну або морфологічну природу. Здебільшого розбіжності стосуються лише компонентного складу фразеологічної одиниці, крім того, як показують приклади, компоненти, що розмежовують, зазвичай є лексемами подібної концептуальної або суміжної семантики. Серед часткових еквівалентів виокремлюються
\end{abstract}


три підгрупи. Поділ залежить від рівня відповідності плану змісту та вираження, денотативного значення, стилістичного й емотивно-експресивного відтінку, граматично-структурної організації.

Незважаючи на деякі відмінності у використанні назв кольорів у досліджуваних мовах, більшість фрразеологічних одиниць англійської мови, що містять назви кольорів, під час перекладу українською мовою зберігають свою структуру семантику. Отже, колір є невід'ємною частиною світогляду, менталітету нації, а також відображається в мові його носіїв.

Ключові слова: фразеологічна одиниця, еквівалент, назви кольорів, семантичні та стилістичні особливості.

\section{Introduction}

Comparative study of languages aimed at identifying their similar and distinctive features is an urgent problem of modern linguistics. Of particular interest in this regard are research in the field of phraseology, which most vividly reflects the originality of the life of a particular people, its culture, traditions and mentality. Therefore, knowledge of phraseological units (idioms) is an integral part of language proficiency.

Color names, expressing vital concepts, play an important role in the emergence of idioms, and, consequently, in the development of the entire phraseological system of any language. Having significant aesthetic possibilities (semantic richness and the ability to form new, expressive and figurative meanings), color names are highly used in the process of phraseological nomination. These lexical units constitute a significant component of many phraseological units, since color is one of the most clearly expressed features of an object, and not a single object of the surrounding world exists outside of color, and color characteristics are a necessary element of visualization of the surrounding space.

The relevance of our research is due to the fact that, within the framework of modern linguistic science, the theoretical and practical meaning of phraseological units with color names, which reflect the peculiarities of national consciousness, has not yet been determined, and their place in the linguistic picture of the world has not been studied. The object of the research is the lexical-semantic and functional features of the phraseological equivalents of the English and Ukrainian languages with an element of color name when translated into Ukrainian.

The main research methods are determined by the purpose, objectives and material of the study. To establish the semantics of the units of analysis, the method of dictionary definitions was used. In order to inventory and classify the units of analysis, as well as to interpret the results of this analysis, a descriptive method was used.

The study of color named in Ukrainian, Russian and Western linguistics was carried out by T.J. Bennett (Bennett, 1988), B. Berlin (Berlin, 1969), F. Birren (Birren, 1978), I. Humeniuk (Humeniuk, 2020), P. Kay (Kay, 2000), S. Kerttula
(Kerttula, 2002), G.C. Newton (Newton, 1988), A. Wierzbicka (Wierzbicka, 1990), I.V. Kovalska (Kovalska, 2001), R.P. Zorivchak (Zorivchak, 1983), and others. However, this issue, in particular the equivalence of phraseological units with a color names, is not sufficiently studied and requires a thorough analysis.

\section{Phraseological equivalence withing lan-} guages

Thus, according to V.V. Krasnykh, adequate translation is the choice of the equivalent, which has an impact on the same areas of cognitive space and structure as the original one (Krasnykh, 2002). Researcher L.K. Latyshev believes that the transfer of meaning and display of the figurativeness of phraseological units, that is, the preservation of the communicative and pragmatic potential is the most important (Latyshev, 2003). According to B.T. Kasharokov, when translating phraseological units it is necessary to pay attention to the following four aspects: 1) linguistic depends on the competence of the translator and knowledge of the original language, mastery of imagery. This aspect includes knowledge of linguistic and linguistic and cultural realities concerning historical events, traditions and customs; 2) cognitive is based on the background knowledge of the translator, namely, knowledge of the subject and subject (the choice of language means is important to ensure the availability of perception and understanding of the text); 3) situational concerns the translator's awareness of the situation (context) without the presence of a keyword; 4) pragmatic is based on the subjective knowledge of the translator (Kasharokov, 2003: 206-207).

Comparative study of phraseological units with an element of color in English and Ukrainian aims to identify and study allomorphic and isomorphic characteristics at the phraseological level, selection and study of complete and partial equivalents and analogues in two languages, and non-equivalent idioms that have no counterparts in the phraseological system of another language.

In our opinion, the most complete and clear definition of the criteria of interlingual equivalence of phraseological units is given in the works of R.P. Zorivchak, I.M. Kovalska (Zorivchak, 1983; Kovalska, 2001). 
R.P.Zorivchak understands under full equivalence the same subject-grammatical meaning, structural-grammatical design, equal concrete (denotative) imagery and similar functional-stylistic and expressive-emotional connotations of idioms (Zorivchak, 1983). Analyzing a large amount of factual material, the researcher identifies full and partial phraseological equivalents and shows the possibility of creating full adequacy in translation.

Y.M. Solodukho divides phraseological equivalents into identical equivalents - those that are characterized by a high degree of formal, semantic and stylistic similarity; direct equivalents - formations characterized by full or partial semantic and stylistic correspondence, parallel lexical structure or grammatical structure; synonymous equivalents - idioms with a motivated logical-semantic basis, which is characterized by the correspondence of logical-figurative and logical-phraseological ideas and stylistic characteristics (Alefirenko, 2008: 24-25).

Phraseological methods of reproduction in translation of semantic and stylistic functions of the original can only be used if there are units in the phraseological foundations of the receptor language whose semantic and stylistic functions are adequate to the same functions of the phraseology of the original.

Depending on the differences in terms of expression, the degree of correspondence of interlanguage phraseological equivalents can be manifested as follows: 1) full equivalence, that is, full correlation of the expression plan and the content plan of idioms; 2) partial equivalence, which is characterized by insignificant differences in terms of expression of idioms with identical semantics.

\section{Full phraseological equivalents}

Full equivalents can be considered phraseological units of the English and Ukrainian languages, which have the same significative-denotative meaning, subjective-evaluative, functional-expressive connotation, structural-grammatical organization and component composition. At the same time, the correspondence of the structural-grammatical organization of the English and Ukrainian idioms implies taking into account the specifics of typological features characteristic of one language and not characteristic of another. The same significative-denotative meaning and subjective-evaluative connotation are determined by an equal set of integral and differential semes.

Thus, such idioms as look through the rosy spectacles and дивитись крізь рожеві окуляри are full equivalents.
Both phraseological units refer to interstyle or neutral units, built on the same image (therefore, the emotional-expressive connotation coincides), they have the same component composition. The structural and grammatical organization is also the same: they both belong to the class of verbal phraseological units and are built according to the model $\mathrm{v}+$ prep + adj $+\mathrm{n}(\mathrm{verb}+$ preposition + adjective + noun).

Idioms Red cock and червоний півень also enter into a relationship of complete equivalence, coinciding in significant-denotative meaning, positive evaluative connotation, belonging to a neutral style, emotionally-expressive connotation. The component composition also coincides: both idioms belong to the class of substantive (noun) phraseology with the structure adj $+n$ (adjective + noun).

Phraseological unit white crow in the meaning "a person who stands out with something unusual" is the complete equivalent of the Ukrainian idiom біла ворона. Significant-denotative meaning and subjective-evaluative connotation are expressed by a set of only integral seven characteristics of a person, negative evaluation and seven differences as traits.

Both phraseological units are neutral or interstyle units, built on the same image, do not have intensities in dictionary definitions; belong to the class of substantive idioms with the structure $\operatorname{adj}+n$ (adjective + noun) and their vocabulary completely coincides.

Moe examples: golden mean - золота середина; golden wedding - золоте весілля; silver wedding - срібне весілля; golden age - золотий вік; golden rule - золоте правило; golden calf- золотий телець; golden mine - золота жила; black ingratitude - чорна невдячність; a blue stocking - синя панчоха; the devil is not so black, as he is painted-дidько не такий чорний, як його малюють еtс.

\section{Partial phraseological equivalents}

Partial phraseological equivalents are characterized by insignificant differences in terms of expression of idioms of identical semantics, which may have a component or morphological nature. In most cases, the discrepancies relate only to the component composition of the phraseological unit, moreover, as the examples show, the components that delimit, as a rule, are lexemes of similar conceptual or related semantics. Among the partial equivalents, in turn, 3 subgroups can be distinguished.

The first subgroup includes phraseological units of English and Ukrainian languages, which differ in only one component of related semantics. 
English idiom milk and roses with the meaning of "Beautiful, ruddy, with a healthy complexion" enters into a relationship of partial equivalence with the Ukrainian phraseological unit кров з молоком. Significative-denotative meaning and subjective-evaluative connotation of comparable phraseological units are determined by the same set of semantic features. Both phraseological units refer to interstyle units. In terms of emotionality, expressiveness - this is a pathetic idiom. In both English and Ukrainian, it has the following structure $\mathrm{n}+$ prep $+\mathrm{n}$ (noun + preposition + noun) in the class of nouns. The differing components of кров and roses have a common meaning - red color.

Also we can compare the idioms golden days and золота доба. They have the same meaning of "happy time". Both language units belong to the neutral style. The structure of these idioms: adj $+n$ (adjective + noun). Different components days and доба have similar meaning - time space. Therefore, these idioms can be attributed to the first group of subgroups of partial equivalents.

More examples: blank spot - біла пляма; to give a green light - давати зелену вулицю; white man - біла кисть; red sеа - червона юшка; red as a lobster - червоний як рак; to blush like a rose - почервоніти як мак; grey hairs - сива борода etc.

In this subgroup of partial equivalents we observe full compliance of the content plan with minor differences in terms of expression: compliance of significant-denotative meaning and subjective-evaluative connotation (same set of semantic features), their functional-stylistic and emotional-expressive connotation and structural. The component composition of phraseology is characterized by close similarity. Differences in component composition do not affect the imagery of idioms due to the similarity of their semantics and do not cause changes in the emotional-expressive connotation.

The second subgroup of partial phraseological equivalents in English and Ukrainian includes idioms that differ in one component of related (non-adjacent) semantics in the presence of also variable components.

Consider the following examples:

The phraseological unit for a rainy day enters into a relationship of partial equivalence with the Ukrainian idiom про/на чорний день/ годину. They have the same meaning "in case of financial hardship, unhappy period". Both English and Ukrainian phraseological units refer to interstyle units. The structure of the following idioms: prep $+\operatorname{adj}+n$ (preposition + adjective + noun). Phraseological units differ in adjectives, in the Ukrainian version it is color name чорний, and in the English variant it is adjective rainy, we can draw a parallel between them, given that, due to a natural phenomenon, it really becomes dark black during rain.

Also to the second subgroup we include: to work like a nigger / brute / carthorse / skivvy / dog / beast / galley slave / navy / - працювати як чорний віл еtс.

Thus, idioms of the second subgroup of partial equivalents have the same significative-denotative meaning, subjective-evaluative connotation, functional-stylistic and emotional-expressive connotation, structural-grammatical organization, but differ in one component of adjacent semantics in the presence of also variable components (approximate similarity), does not affect all other aspects of general phraseological meaning. Therefore, we can talk about the coincidence of the content plan with some differences in terms of expression.

The third subgroup of partial phraseological equivalents includes idioms of English and Ukrainian, which have some morphological differences in the use of prepositions, numbers, nouns, and so on.

Of particular interest are phraseological units fish in troubled waters and ловити рибу в мутній вод $i$ with the meaning of "seek benefit for yourself in the misery of others". In this case, the significative-denotative meaning, subjective-evaluative, functional-stylistic, emotional-expressive connotations coincide and we see the similarity of the structural organization, these phraseological units differ in the category of the number of the nouns waters and водa, the components of the adjacent semantics troubled and мутній and the expression of the same general meaning in English using the verb fish, and in Ukrainian by using the collocation ловити рибу. That is, in these idioms we observe partial changes in the component composition.

More examples: to kill the goose that lays golden eggs - нема тієі курочки, щуо несла золоті яєчка еtс.

So, the phraseological units of the English and Ukrainian languages, belonging to the third subgroup of phraseological equivalents, have a common significative-denotative meaning, subjective-evaluative, functional-stylistic and emotionally-expressive connotations, differences in the structural-grammatical organization and the same or slightly different component 
composition, that is, full compliance with the content plan and partial differences in terms of expression.

It should also be noted that the tokens of the Ukrainian and English languages, which occupy the core and the close periphery of the lexical-semantic field of color, are generally characterized by the convergence of the denotative macrocomponent. Only in some cases there is an undifferentiated value, such as in the correlations "blue" - «синій», «голубий», «блакитний»; "purple” - «пурпуровий», «бузковий», «багряний»; "grey” - «сірий», «сивий» etc. Divergence can be traced mainly at the level of usual, personal, functional and stylistic connotations of color designations, emotional, expressive and evaluative components of meaning, associations and color symbolism.

The fact that phraseological units, as linguistic units, reflect the specifics of the worldview of a particular nation, is an indisputable truth. Consider some phraseological equivalents with color names in the studied languages.

As a rule, when translating phraseological units of the English language into Ukrainian using color names, an exact match of the lexeme is used to denote a color: as red as a lobster-червоний, як рак; blue blood - голуба кров; a white crow біла ворона. The token "green" is used to denote inexperience, but in different languages in combination with different tokens: green hand молодий та зелений.

However, there is a certain number of idioms in which, when translated into another language, a different color name is used.

In English, the color green is used to indicate envy: green with envy (tormented by envy), to look through green glasses (to envy), greeneyed monster (envy). In the Ukrainian language we find an expression заздрість із жовтими очима, мов жсовтки. In the color spectrum, green and yellow stand side by side, so it is not surprising that both color names are used. The use of these color names in the sense of envy is associated with physiological processes in the human body. When a person feels envy, jealousy, he intensely secretes bile, and the skin becomes yellow-green.

The state of anger, rage is also expressed by various color names in each of the languages. Red color is used in the English language - to see red; yellow and blue are inherent in the Ukrainian language - жовтіти (синіти) від злості.

The translation of the phrase also differs to drink till all's blue-допитися до білої гарячки.
The same with the blue devils (the second meaning), it is interpreted as біла гарячка (delirium tremens).

As noted above, the token green in English and Ukrainian can mean "inexperienced" and denoting this meaning become a part of idiom.

However, in the Slavic language there is another phrase with a different color name and the same semantics: жовтороте пташеня (yellow chick). Similar semantics arises at interaction of values of two tokens which are a part of idiom.

\section{Conclusions}

Having considered phraseological ways of reproduction of semantic and stylistic functions of phraseology of the original and having analyzed phraseological equivalents with color designations, some theses are suggested.

The terms full phraseological equivalent and partial phraseological equivalent, based on the general definition of the equivalent - "a unit of speech that coincides with a function with another and is able to perform the same function as another unit of speech" have been distinguished.

In phraseological ways of reproducing the phraseology of the original, subjective factors play an important role, along with objective factors, ie the presence of the same semantic and stylistic characteristics in both languages, primarily related to translation skills, experience and talent of translators.

In binary comparisons it is necessary to take into account the subject-logical meaning of phraseology, imagery, functional-stylistic and expressive-emotional connotations, structural-grammatical structure.

The material of the study showed that in most cases the color designations have equivalent coincidences in the original language and in the translated language. In our opinion, this phenomenon can be explained by the fact that in two languages the fields of the main color designations coincide; despite belonging to different cultures, native speakers of English and Ukrainian have much in common in the perception of color space.

So, despite some differences in the use of color names in the studied languages, the overwhelming majority of the idioms of the English language containing the names of colors, when translated into Ukrainian, retain their structure. Color is an integral part of a nation worldview, mentality, and is also reflected in the language of its speakers. 


\section{BIBLIOGRAPHY:}

1. Алефиренко Н.Ф. Фразеология в свете современных лингвистических парадигм. Москва : Элпис, 2008. 271 с.

2. Bennett T.J. Aspects of English Colour Collocations and Idioms. Heidelberg : Carl Winter, 1988. 197 p.

3. Berlin B., Kay P. Basic Color Terms: Their Universality and Evolution. Berkeley ; Los Angeles : University of California Press, 1969. $178 \mathrm{p}$.

4. Birren F. Color and human response. New York : Van Nostrand Reinhold Company, 1978. 141 p.

5. Humeniuk I.I. Philosophy of red color: linguistic and extralinguistic aspects. Wisdom. 2020. № 15(2). P. 188-198.

6. Кашкаров Б.Т. Пословицы русского, немецкого и кабардино-черкесского языков - источник изучения культурно-языкового сознания (структурно-семантический и лингвокультурный аспекты) : монография. Черкесск : КЧ РИПКРО, 2003. 246 с.

7. Kay P. Color. Journal of Linguistic Anthropology. 2000. № 9. P. 29-32.

8. Kay P. Color. Key terms in language and culture. New York: Alessandro Duran Blackwell Publishers, 2001. P. 27-29.

9. Kerttula S. English colour terms: etymology, chronology and relative basicness. Helsinki : Societe neophilologique de Helsinki, 2002. 364 p.

10. Ковальська І.В. Кольористика як перекладознавча проблема (на матеріалі українських і англомовних текстів). Київ, 2001. 19 с.

11. Красных В.В. Этнопсихолингвистика и лингвокультурология Москва : Гнозис, 2002. 284 с.

12. Латышев Л.К. Перевод: теория, практика и методика преподавания. Москва : Академия, 2003. 192 с

13. Newton G.C. Polemics and the project for a new science of color. Cambridge : Cambridge University Press, 1988. $222 \mathrm{p}$

14. Зорівчак Р.П. Фразеологічна одиниця як перекладознавча категорія. Львів : Вища школа, 1983. 175 с.

15. Wierzbicka A. The Meaning of Color Terms: Semantics, Culture and Cognition. Cognitive Linguistics. 1990. № 1. P. 99-150.

\section{REFERENCES:}

1. Alefirenko, N.F. (2008). Frazeologia v svete sovremennykh lingvisticheskikh paradigm [Phraseology in the aspect of modern linguistic paradigms]. M.: Elpis, $271 \mathrm{p}$.
2. Bennett, T. J. (1988). Aspects of English Colour Collocations and Idioms. Heidelberg: Carl Winter. 197 p.

3. Berlin, B., Kay, P. (1969). Basic Color Terms: Their Universality and Evolution. Berkeley and Los Angeles: University of California Press. 178 p.

4. Birren, F. (1978). Color and human response. New York: Van Nostrand Reinhold Company. 141 p.

5. Humeniuk, I.I. (2020). Philosophy of red color: linguistic and extralinguistic aspects. Wisdom. 15 (2). 188-198. https://doi.org/10.24234/wisdom.v15i2.342

6. Kasharokov, B.T. (2003). Poslovitsy russkogo, nemetskogoikabardino-cherkesskogo yazykov-istochnik izucheniya kulturno-yazykovogo soznaniya (strukturnosemanticheskiy i lingvokulturnyy aspekty) [Proverbs of Russian, German and Kabardino-Cherkessian languages - the source of learning of cultural and language conscience (structural and semantic and linguacultural aspects)]. Cherkesk: KCh RIPKRO. 246 p.

7. Kay, P. (2000). Color. Journal of Linguistic Anthropology. № 9. 29-32.

8. Kay, P. (2001). Color. Key terms in language and culture. New York: Alessandro Duran Blackwell Publishers. 27-29.

9. Kerttula, S. (2002). English colour terms: etymology, chronology and relative basicness. Helsinki: Societe neophilologique de Helsinki. 364 p.

10. Kovalska, I.V. (2001). Kolorystyka yak perekladoznavcha problema (na materiali ukraiinskyh I anhlomovnyh tekstiv) [Coloristics as a translation problem (based on Ukrainian and English-language literary texts)]. Kyiv. 19 p.

11. Krasnykh, V.V. (2002). Etnopsikholingvistika i lingvokulturologiya [Ethnopsycholinguistics and linguoculturology]. M.: Gnozis. 284 p.

12. Latyshev, L.K. (2003). Perevod: teoriya, praktika i metodika prepodananiya [Translation: theory, practice and methodics of teaching]. M.: Akademiya. $192 \mathrm{p}$.

13. Newton, G.C. (1988). Polemics and the project for a new science of color. Cambridge: Cambridge University Press. $222 \mathrm{p}$.

14. Zorivchak, R.P. (1983). Frazeolohichna odynytsia yak perekladoznavcha katehoriia [Phraseological unit as a translation category]. Lviv: Vyshcha shkola. $175 \mathrm{p}$.

15. Wierzbicka, A. (1990). The Meaning of Color Terms: Semantics, Culture and Cognition. Cognitive Linguistics. 1. 99-150.

Стаття надійшла до редакиії 09.10.2020. The article was received October 9, 2020. 